for the Siluro-Devonian boundary will be of considerable value, since it will facilitate direct correlations between rocks of this age in Britain and those in Central Europe. In fact it has already received support from various quarters both here and abroad, and it is to be hoped that the remaining members of the Ludlow Research Group will now be persuaded to follow Dr. Holland's courageous stand.

Once this is achieved, the only serious problem remaining is how to name the beds above those of the British Ludlovian Stage, now brought within the Silurian. Dr. Jaeger tends to favour the retention of the name Downtonian for them, but since the change was due in large measure to the unsatisfactory nature of the Ludlow Bone Bed for correlating with the Continental sequence, using his name would still leave us with the same problem. For this reason I have suggested that it might be preferable to extend the Ludlovian to include the beds in question, as there seems little justification for interpolating an entirely new Stage between the marine Ludlovian and the Gedinnian. In any event there is a historical precedent for including the re-defined Downtonian in the Ludlovian, for Murchison originally included the Ludlow Bone Bed, the Downton Castle Sandstone, and the Tilestone Formation within his Upper Ludlow Rock.

\title{
REFERENCES
}

Holland, C. H., 1965. The Siluro-Devonian Boundary. Geol. Mag., 102, 213-22i.

JAEGER, H., 1964. Beiträge zur regionalen Geologie Thüringens und angrenzender Gegiete sowie zu anderen Problemen. Abh. deutsch. Akad. Wiss. Berlin, 1964, 27-51.

1965. Referate. Symposium-Band der 2. Internationalen Arbeitstagung uber die Silur/Devon-Grenze. Geologie. Berlin, 14, 348-364.

TARlo, L. B. H., 1964. Psammosteiformes (Agnatha)-a review with descriptions of new material from the Lower Devonian of Poland. 1. General Part. Palaeont. polon., 13, 1-135.

1965. Discussion in Dineley, D. L., Demonstration : Ostracoderms from the Siluro-Devonian of Somerset Island, Arctic Canada. Proc. Geol. Soc. Lond., 1624, 98.

Department of Geology,

L. B. Halstead Tarlo.

UNIVERSITY OF READING.

31 st July, 1965 .

\section{K-A STUDIES IN SCOTLAND}

SiR,--Our paper in the March-April issue of this magazine included in Table 3 ages for specimens of Dalradian schists from near Loch Fyne (localities numbered 45 to 50 ). We wish to record that all these specimens were from the vicinity of Sithean Sluaigh and their grid references are as follows :-

$\begin{array}{cc}\text { Locality } & \text { No. } \\ 45 & \text {. } \\ 46 & : \\ 47 & : \\ 48 & : \\ 49 & : \\ 50 & \text {. }\end{array}$

Grid Reference.

NS 072981

NS 067978

NS 067980

NS 073979

NS 073979

NS 067980

In addition, there is an omission in the grid reference of locality 72 which should read NN 590930 and a mis-spelling in locality No. 93 which should read 'S Airde Beinn.
Department of Geodesy and
J. A. Miller.
Geophysics, CAMBRIDGE.
DEPARTMENT OF GeOLOGY,
P. E. Brown.

SHEFFIELD.

12th July, 1965. 